University of Nottingham

12-15 JULY 1993

NUTRITIONAL ASPECTS OF RECOVERY FROM SEVERE ILLNESS AND SURGERY

Chairmen: S. P. ALLISON, Nottingham

P. ROGERS, Reading

Development of food aversions during illness. Ilene L. Bernstein

Appetite and nutrition in relation to human immunodeficiency virus (HIV) infection and acquired immunodeficiency virus syndrome (AIDS). Carolyn Summerbell

University of Nottingham

12-15 JULY 1993

NUTRITION AND ACTIVITY

Chairman: A. M. Prentice, Dunn, Cambridge

Nutritional implications of work in draught animals. Anme Pearson \& Jeroen T. Dijkman

Nutritional aspects of endurance exercise in humans. $R$. J. Maughan

Diet and exercise performance in the horse. David L. Frape

Energy expenditure and physical activity in relation to fitness in children. M. B. E. Livingstone

Physical activity, protein metabolism and protein requirements. D. Joe Millward, Joanna L. Bowtell, Paul Pacy \& Michael J. Rennie

Physical activity, undernutrition and child development. J. M. Meeks Gardner \& S. M. Grantham-McGregor

University of Nottingham

12-15 JULY 1993

ICONS WORKSHOP REPORT

Chairman: B. MARGETTS, Southampton

Nutrition information and support for overseas members. Ann Burgess

\title{
ABSTRACTS OF COMMUNICATIONS
}

\section{University of Nottingham}

12-15 JULY 1993

Copying. This journal is registered with the Copyright Clearance Center, 27 Congress St., Salem, Mass. 01970. Organizations in the USA who are also registered with C.C.C. may therefore copy material (beyond the limits permitted by sections 107 and 108 of US Copyright law) subject to payment to C.C.C. of the per-copy fee of $\$ 5$. This consent does not extend to multiple copying for promotional or commercial purposes. Code 0029-6651/94/4900-4900 \$5. Organizations authorized by the Copyright Licensing Agency may also copy material subject to the usual conditions.

ISI Tear Sheet Service, 3501 Market Street, Philadelphia, Pennsylvania 19104, USA, is authorized to supply single copies of separate articles for private use only.

For all other use, permission should be sought from the Cambridge or American Branch of Cambridge University Press. 


\title{
Society
}

VOL. 53 No. 1 MARCH 1994

\section{CONTENTS}

\section{SYMPOSIUM PROCEEDINGS}

University of Nottingham

12-15 JULY 1993

KEYNOTE LECTURES

Chairmen: A. J. F. WEBSTER, Bristol

I. A. Macdonald, Nottingham

The application of nutritional science to clinical practice $M$. Elia

\author{
University of Nottingham \\ 12-15 JULY 1993 \\ NUTRITIONAL EPIDEMIOLOGY \\ Chairman: M. E. J. LEAN, Glasgow
}

Dietary fat and risk of breast and colon cancer. Walter $C$. Willett

Measuring nutritional exposures including biomarkers. Pieter van 't Veer

Measurement error: effects and remedies in nutritional epidemiology. David Clayton

University of Nottingham

12-15 JULY 1993

ANTIOXIDANTS

Chairman: J. R. ARTHUR, Rowett, Aberdeen

Can dietary micronutrients influence tissue antioxidant capacity? Malcolm J. Jackson

Epidemiology and the role of antioxidants in preventing coronary heart disease: brief overview. Rudolph $A$.

Riemersma

Micronutrients and oxidative stress in the aetiology of cancer. Andrew Collins, Susan Duthie \& Marion Ross

Carotenoids: functions and fallacies. David I Thurnham

\author{
University of Nottingham \\ 12-15 JULY 1993 \\ REPRODUCTION AND FERTILITY \\ Chairman: C. KNIGHT, Ayr
}

The role of nutrition and photoperiod in the timing of puberty. Clare L. Adam \& John J. Robinson

Relationships between nutrition, puberty and mammary development in cattle. Kris Sejrsen

The right weight: body fat, menarche and fertility. Rose E. Frisch 